\title{
ISONIAZID ACETYLATING PHENOTYPE IN PATIENTS WITH PARACOCCIDIOIDOMYCOSIS AND ITS RELATIONSHIP WITH SERUM SULFADOXIN LEVELS, GLUCOSE-6-PHOSPHATE DEHYDROGENASE AND GLUTATHIONE REDUCTASE ACTIVITIES.
}

\author{
Benedito Barraviera, Paulo Câmara Marques Pereira, \\ Jussara Marcondes Machado, Maria Julia de Souza, \\ Carlos Roberto G. Lima, Paulo Roberto Curi, Rinaldo Poncio Mendes \\ and Domingos Alves Meira.
}

\begin{abstract}
The authors evaluated the isoniazid acetylating phenotype and measured hematocrit, he moglobin, glucose-6-phosphate dehydrogenase and glutathione reductase activities plus serum sulfadoxin levels in 39 patients with paracoccidioidomycosis ( 33 males and 6 females) aged 17 to 58 years. Twenty one (53.84\%) of the patients presented a slow acetylating phenotype and 18(46.16\%) a fast acetylating phenotype. Glucose-6-phosphate-dehydrogenase (G6PD) activity was decreased in $5(23.80 \%)$ slow acetylators and in $4(22.22 \%$ ) fast acetylators. Glutathione reductase activity was decreased in 14(66.66\%) slow acetylators and in 12(66.66\%) fast acetylators. Serum levels of free and total sulfadoxin were higher in slow acetylator $(p<0.02)$. Analysis of the results permitted us to conclude that serum sulfadoxin levels are related to the acetylator phenotype. Furthermore, sulfadoxin levels were always above $50 \mu \mathrm{g} / \mathrm{ml}$, a value considered therapeutic. Glutathione reductase deficiency observed in $66 \%$ of patients may be related to the intestinal malabsorption of nutrients, among them riboflavin, a FAD precursor vitamin, in patients with paracoceidioidomycosis.
\end{abstract}

Key-words: Isoniazid acetylating phenotype Paracoccidioidomycosis. Glucose-6-phosphate dehydrogenase (G6PD). Glutathione reductase. Sulfadoxin.

The therapeutic conduct adopted by us thus far $^{6} 18$ for paracoccidioidomycosis is divided into two stages, i.e. acute and maintenance treatment. Several drugs have been employed for acute treatment, among them sulfa drugs alone 17 or in combination with trimethoprim 5718 . For maintenance, the use of slowexcretion sulfa drugs is recommended for a period of at least two years 18 . These drugs, because of their oxidizing action, may cause serious side effects in patients with genetic red blood cell defects 1346914 21. Among such defects are glucose-6-phosphate dehydrogenase (G6PD) and glutathione reductase deficiency ${ }^{3} 14$. Glutathione reductase deficiency also may be an acquired defect due to deficiency of riboflavin, a FAD precursor vitamin ${ }^{9} 14$. These

Department of Infectious and Parasitologic Diseases, and Section of Statistics, School of Medicine of Botucatu, University Paulist State, São Paulo, SP, Brazil.

Research Supported by FUNDUNESP, Grant 007/89 and CNPq, Grant 300398/88-3.

Correspondence address: Dr. Benedito Barraviera, Faculdade de Medicina de Botucatu/UNESP, CP: 576, 18610 Botucatu, SP, Brasil.

Recebido pera publicação em 28/12/90. defects may cause attacks of hemolytic anemia in patients treated for paracoccidioidomycosis, with consequent severe worsening of clinical signs and prognosis.

In addition, the literature is controversial with respect to the effect of isoniazid acetylating phenotype on serum levels of sulfones, sulfonamides and isoniazid. Some investigators 81027 believe that the acetylating phenotype is intimately related to the serum levels of these drugs, whereas others 24 disagree.

In view of the above considerations, the objectives of the present study were to determine the isoniazid acetylating phenotype and to evaluate correlation of it with G6PD and glutathione reductase activity and with serum levels of free and total sulfadoxin in patients with paracoccidioidomycosis.

\section{MATERIAL AND METHODS}

The present study was conducted at the Paracocciodioidomycosis Outpatient Clinic of the Division of Infectious and Parasitologic Diseases of the School of Medicine of Botucatu/UNESP, São Paulo, Brazil, from 1987 to 1989 . Thirty-nine patients ( 6 females and 33 males, aged 19 to 64 years) with a confirmed diagnosis of paracoccidioidomycosis were studied. The clinical form of the disease ${ }^{13}$ was chronic in 29 and subacute progressive in 10 patients. All patients 
were under maintenance treatment with one tablet (500 mg) of sulfadoxin twice a week. As recommended by Mendes 18 , the medication was taken on Mondays and Thursdays and blood samples were collected on Wednesdays at about 2:00 p.m.. All patients had been under maintenance treatment for at least one month and followed medical prescriptions rigorously. They were tested for isoniazid acetylating phenotype and G6PD and glutathione reductase activities and submitted to measurement of hematocrit, hemoglobin and serum levels of free and total sulfadoxin.

Isoniazid acetylating phenotype was determined before the beginning of treatment by the colorimetric test of Eidus et al ${ }^{12}$ and Hodgkin et al ${ }^{15}$ and the patients were classified as fast acetylators when acetylated isoniazid was more than $65 \%$ and as slow acetylators when acetylated isoniazid was less than $65 \%$, according these authors 1215 .

G6PD and glutathione reductase activities were determined by the technique standardized by Barraviera et $\mathrm{al}^{3}$. The normal values were $221.10 \pm 21.06$ $\mu \mathrm{g} / \mathrm{min}$ for G6PD activity, and $81.27 \pm 9.54 \mu \mathrm{g} / \mathrm{min}$ for glutathione reductase. Hematocrit levels were determined by the microhematocrit method and hemoglobin levels by the cyanomethemoglobin method 20 .

Serum sulfadoxin levels were measured by the techique of Bratton \& Marshall11 which is used to evaluate free and total sulfadoxin levels.

Two study groups were proposed for evaluation of the results: Group 1: slow acetylators; and Group 2: fast acetylators.

Data were analyzed statistically using the paired " $\mathrm{t}$ " test 25 . To determine the interrelationship of the variables, the linear correlation coefficient between pairs of variables was calculated.

\section{RESULTS}

Analysis of the results presented in Table 1 showed that $21(53.84 \%)$ patients were slow acetylator and $18(46.16 \%)$ fast acetylators.
Hematocrit and hemoglobin levels were reduced only among male patients, 5 of whom $(27.77 \%)$ were fast acetylators and $6(28.57 \%)$ slow acetylators.

G6PD activity was decreased in $5(23.80 \%)$ slow acetylators and $4(22.22 \%)$ fast acetylators. Glutathione reductase activity was decreased in $14(66.66 \%)$ slow acetylators and in $12(66.66 \%)$ fast acetylators.

Serum levels of free and total sulfadoxin were significatively higher among slow acetylators ( $p \leq 0,05$ and $p<0,02$, respectively). There was a negative correlation between slow acetylating plenotype and serum level of free sulfa $\left(\mathrm{r}_{0,01}=-0,45\right)$.

\section{DISCUSSION}

Isoniazid acetylating phenotype and G6PD and glutathione reductase activities are genetically determined traits 368101215 . The first is determined by major autosomal genes and is related to the acetylating capacity of hepatic acetyl transferase. One of the functions of this enzyme is to inactivate sulfones, sulfonamides and isoniazid 101215 . Population studies 1926 have demonstrated two types of acetylators, i.e., fast and slow, the frequency of each varying from population to population. American Indians, Japanese and Eskimos most often present a fast acetylating phenotype ${ }^{26}$. In Brazil, Beiguelman et al ${ }^{10}$ evaluated the acetylating phenotype of Caucasian and Black patients with tuberculosis and detected $57 \%$ slow acetylators among Caucasians and 50\% among Blacks. In the present study, the prevalence of acetylating phenotype was quite similar to that found by these investigators 10 .

G6PD activity is determined by genes located on the $\mathrm{X}$ chromosome ${ }^{14} 21$. Thus, only females can manifest homozygous or heterozygous trait. In the present study, 3 patients heterozygous for G6PD deficiency were detected. Among the six G6PDdeficient male patients, only two developed anemia. It should be pointed out that reduced number of patients

Table 1 - Distribution of acetylating phenotype, hematocrit, hemoglobin, glucose-6-phosphate dehydrogenase (G6PD) and gluthatione reductase (GR) activities and serum levels of total and free sulfadoxin.

\begin{tabular}{|c|c|c|c|c|c|c|}
\hline $\begin{array}{l}\text { Acetylating } \\
\text { phenotype }\end{array}$ & $\begin{array}{c}\text { Hematocrit } \\
(\%) \\
\overline{\mathrm{X}} \pm \mathrm{s}\end{array}$ & $\begin{array}{l}\text { Hemoglobin } \\
\begin{array}{c}(\mathrm{g} \%) \\
\overline{\mathrm{X}} \pm \mathrm{s}\end{array}\end{array}$ & $\begin{array}{c}\text { G6PD } \\
(\mu \mathrm{g} / \mathrm{min}) \\
\overline{\mathrm{X}} \pm \mathrm{s}\end{array}$ & $\begin{array}{c}\text { GR } \\
(\mu \mathrm{g} / \min ) \\
\overline{\mathrm{X}} \pm \mathrm{s}\end{array}$ & $\begin{array}{c}\text { Total } \\
\text { Sulfadoxin } \\
(\mu \mathrm{g} / \mathrm{ml}) \\
\overline{\mathrm{X}} \pm \mathrm{s}\end{array}$ & $\begin{array}{c}\text { Free } \\
\text { Sulfadoxin } \\
(\mu \mathrm{g} / \mathrm{ml}) \\
\overline{\mathrm{X}} \pm \mathrm{s}\end{array}$ \\
\hline $\begin{array}{l}\text { Slow } \\
n=21)\end{array}$ & $\begin{array}{c}49.61 \pm \\
7.54\end{array}$ & $\begin{array}{c}14.46 \pm \\
2.21\end{array}$ & $\begin{array}{c}208.42 \pm \\
38.46\end{array}$ & $\begin{array}{l}62.73 \pm \\
21.08\end{array}$ & $\begin{array}{c}190.24 \pm \\
54.10\end{array}$ & $\begin{array}{c}154.04 \pm^{* *} \\
41.54\end{array}$ \\
\hline $\begin{array}{l}\text { Fast } \\
(n=18)\end{array}$ & $\begin{array}{c}48.88 \pm \\
7.01\end{array}$ & $\begin{array}{c}13.76 \pm \\
1.95\end{array}$ & $\begin{array}{c}214.03 \pm \\
31.01\end{array}$ & $\begin{array}{l}64.26 \pm \\
16.24\end{array}$ & $\begin{array}{c}152.98 \pm \\
37.91\end{array}$ & $\begin{array}{c}125.04 \pm \\
32.39\end{array}$ \\
\hline
\end{tabular}

Statistical analysis: ${ }^{*} \mathrm{t}=2.45 ; \mathrm{p}<0.02$.

* $t=2.40 ; p<0.05$; differences significatives in respect to the fast acetylating group. 
Bamaviera B, Pereira PCM, Machado JM, Souza MJ, Lima CRG, Curi PR, Mendes RP, Meira DA. Isoniazid acetylating phenotype in patients with paracoccidioidomycosis and its relationship with serum sulfadoxin levels, glucose-6-phosphate dehydrogenase and glutathione reductase activities. Revista da Sociedade Brasileira de Medicina Tropical 24:111-114, abr-jun, 1991

with anemia detected among deficient individuals under the effect of oxidizing drugs such as sulfadoxin can be explained by the type of deficiency predominating in Brazilian populations 14 . The deficiency encountered here is possibly of the African type, with a consequent tolerance of red cells to oxidizing drugs 3461421 .

From a genetical viewpoint, glutathione reductas deficiency follows the autosomal recessive model, the detection of deficient individuals being a very infrequent occurrence ${ }^{114}$. For perfect functioning, this enzyme needs NADPH generated through the pentose pathway 31421 and FAD, a phosphorylated riboflavin derivative ${ }^{2} 9$. Barraviera et $\mathrm{al}^{2}$, in a study of individuals from the Brazilian Amazon region, detected decreased glutathione reductase activity due to riboflavin deficiency caused by the peculiar dietary habits of that region. In addition, the elevated rate of helminth infestation detected among Amazon populations may strongly contribute to the consumption of this vitamin 16 . The elevated prevalence of glutathione reductase observed in the present study may have been related to the intestinal malabsorption of nutrients, among them amino acids and vitamins, observed among patients with progressive paracoccidioidomy$\operatorname{cosis}^{7} 17$.

On the other hand, individuals chronically using sulfamide derivatives are known to suffer stimulation of glutathione synthetase which causes increased synthesis of reduced glutathione ${ }^{23}$. These individuals eventually show an increase in glutathione reductase activity. The present findings showed exactly the contrary, i.e., a decrease in glutathione reductase activity, strengthening the hypothesis that the nutritional deficiency of riboflavin may be the limiting factor in glutathione reductase activity. It should be pointed out that all anemic patients presented decreased glutathione reductase activity. It has been reported 1691421 that the same drugs that cause anemia among G6PD-deficient individuals can cause anemia among glutathione reductase-deficient subjects. In this case, the nutritional deficiency on the one hand, the chronic effect of sulfadoxin on the other, may have strongly contributed to the onset of anemia.

The relationship between acetylating phenotype and serum levels of fast-excretion sulfamide derivatives are controversial ${ }^{24} 27$. Vree et al 27 and Barraviera et $\mathrm{al}^{8}$, when evaluating the serum sulfadiazine levels of patients using these drugs and their relationship with the acetylating phenotype, found more elevated drug levels and decreased renal function among slow acetylators. The present results agree with those reported in these studies 827 and clearly demonstrate the difference in serum sulfadoxin levels between slow and fast acetylators. On the other hand, serum levels of free sulfadoxin were always above $50 \mu \mathrm{g} / \mathrm{ml}$ in all patients studied, levels considered therapeutic by Padilha-Gonçalves ${ }^{22}$. Thus, the posology used was appropriat since it maintained satisfactory serum levels of the drug even among fast acetylators.

Finally, determination of acetylator phenotype and of serum sulfadoxin level as well as their relationships with G6PD and glutathione reductase activities represents an important and very useful parameter since it permits better clinical follow-up of the patients, with early observation of the possible onset of anemia and of therapeutic faults due to insufficient circulating levels of the drug.

\section{RESUMO}

Os autores avaliaram o fenótipo acetilador da isoniazida, hematócrito, hemoglobina, atividade da glicose-6fosfato desidrogenase, glutationa redutase e os niveis sércos de sulfadoxina de 39 doentes com paracoccidioidomicose, sendo 33 do sexo masculino e 6 do feminino, com idades compreendidas entre 17 e 58 anos. Vinte e um $(53,84 \%)$ doentes apresentaram fenótipo acetilador lento $e$ $18(46,16 \%)$ rápido. $A$ atividade da glicose- 6 -fosfato desidrogenase (G6PD) esteve diminuída em $5(23,80 \%)$ acetiladores lentos e $4(22,22 \%)$ rápidos. A atividade da glutationa redutase esteve diminuida em 14 (66,66\%) acetiladores lentos e $12(66,66 \%)$ rápidos. Os niveis séricos de sulfadoxina livre e total foram maiores nos acetiladores lentos $(p<0,02)$. A análise dos resultados permite concluir que os niveis séricos de sulfadoxina relaciona-se com o fenótipo acetilador. Além disso, os niveis estiveram sempre acima de $50 \mu \mathrm{g} / \mathrm{ml}$, níveis estes considerados terapêuticos. Por outro lado, a deficiência de glutationa redutase pode estar relacionada com a má absorção intestinal de nutrientes, entre eles riboflavina, vitamina precursora de FAD.

Palavras-chaves: Fenótipo acetilador da isoniazida. Paracoccidioidomicose. Glicose-6-fosfato desidrogenase (G6PD). Glutationa redutase. Sulfadoxina.

\section{ACKNOWLEDGMENTS}

The authors are grateful to FUNDUNESP and CNPq for support.

\section{REFERENCES}

1. Barraviera B. Effect of antimalarial drugs and of clindamycin on erythrocyte metabolism. A review. Revista do Instituto de Medicina Tropical de São Paulo 31: 200 205, 1989.

2. Barraviera B, Machado PEA, Meira DA. Glutathion reductase activity and its relation with riboflavin levels measured by methemoglobin reduction by cystamine in patients with malaria. (Preliminary Report). Revista do Instituto de Medicina Tropical de São 30: 107-108, 1988. 
Barraviera B, Pereira PCM, Machado JM, Souza MJ, Lima CRG, Curi PR, Mendes RP, Meira DA. Isoniazid acetylating phenotype in patients with paracoccidioidomycosis and its relationship with serum sulfadoxin levels, glucose-6-phosphate dehydrogenase and glutathione reductase activities. Revista da Sociedade Brasileira de Medicina Tropical 24: 111-115, abr-jun, 1991

3. Barraviera B, Machado PEA, Meira DA, Curi PR, Martins JNP, Souza MJ. Glucose-6-phosphate dehydrogenase and glutathione reductase activity in methemoglobin reduction by methylene blue and cystamine. Study on glucose-6-phosphate dehydrogenase-deficient individuals, on normal subjects and on riboflavin-treated subjects. Revista do Instituto de Medicina Tropical de São Paulo 30: 370-378, 1988.

4. Barraviera B, Meira DA, Machado PEA, Curi PR. Malária no município de Humaitá, Estado do Amazonas XXI. Prevalência da deficiência de glicose-6-fosfato desidrogenase (G6PD) em amostra da população e em doentes com malária causada pelo Plasmodium falçiparum. Revista do Instituto de Medicina Tropical de São Paulo 29: 374-380, 1987.

5. Barraviera B, Mendes RP, Machado JM, Pereira PCM, Souza MJ, Meira DA. Evaluation of treatment of paracoccidioidomycosis with cotrimazine (combination of sulfadiazine and trimethoprim). Revista do Instituto de Medicina Tropical de São Paulo 31: 53-55, 1989.

6. Barraviera B, Mendes RP, Pereira PCM, Machado JM, Curi PR, Meira DA. Measurement of glucose-6-phosphate dehydrogenase and glutathione reductase activity in patients with paracoccidioidomycosis treated with ketoconazole. Mycopathologia 104: 87-91, 1988.

7. Barraviera B, Paiva SAR, Marques MEA, Machado JCMS. Paracoccidioidomicose subaguda progressiva. Tratamento de um doente com cotrimoxazole e nutrição parenteral. Arquivos Brasileiros de Medicina 63: 406410, 1989.

8. Barraviera B, Pereira PCM, Mendes RP, Machado JM, Lima CRG, Meira DA. Evaluation of acetylator phenotype, renal function and serum sulfadiazine levels in patients with paracoccidioidomycosis treated with cotrimazine (combination of sulfadiazine and trimethoprim). Mycopathologia 108: 107-112, 1989.

9. Barraviera SRCS, Barraviera B, Machado PEA, Habermann MC, Stolf HO, Gonzaga HFS. Uso da riboflavina no tratamento da hemólise pela sulfona em doente com dermatite herpetiforme de Duhring-Brocq deficiente em glutationa redutase. Anais Brasileiros de Dermatologia 64: 231-233, 1989.

10. Beiguelman B, Ramalho AS, Arena JFP, Garlipp CR. A acetilação da isoniazida em brasileiros caucasóides e negróides com tuberculose pulmonar. Revista Paulista de Medicina 89: 12-15, 1977.

11. Bratton AC, Marshall EK. A new coupling component for sulfanilamide. Journal of Biological Chemistry 128: 537-550, 1939.

12. Eidus L, Varughese $P$, Hodgkin MM, Hsu AHE, McRae KB. Simplification of isoniazid phenotyping procedure to promote its aplication in the chemoterapy of tuberculosis. Bulletin of the World Health Organization 49: 507 $516,1973$.
13. Franco MF, Montenegro MR, Mendes RP, Marques SA, Dillon NL, Mota NGS. Paracoccidioidomycosis: a recently proposed classification of its clinical forms. Revista da Sociedade Brasileira de Medicina Tropical 20: 129-132, 1987.

14. Grimes AJ. Human red cell metabolism. Blackwell, London, 1980.

15. Hodgkin MM, Eidus L, Hamilton EJ. Screening of isoniazid inactivators by dilution test. Bulletin of the World Health Organization 51: 428-430, 1974.

16. Marcondes JM, Meira DA, Machado PEA, Barraviera B, Matsubara LS, Vadileti C, Pirolla JAG, Machado EAB. Malária no município de Humaitá, Estado do Amazonas XIV - Inquérito coprológico em habitantes da região em relação às taxas de hemoglobina. Revista do Instituto de Medicina Tropical de São Paulo 24(supl 6): 24-28, 1982.

17. Martinez R, Meneghelli VG, Fiorillo AM, Oliveira RB. O comprometimento gastrintestinal na blastomicose sulamericana (Paracoccidioidomicose) II. Estudo funcional do intestino delgado. Revista da Associação Médica Brasileira 25: 70-72, 1979.

18. Mendes RP. Paracoccidioidomicose. In: Meira DA (ed) Terapêutica de Doenças Infecciosas e Parasitárias, EPUME, Rio de Janeiro p. 175-182, 1987.

19. Motulsky A. Pharmacogenetics. Progress Medical Genetics 3: 49-74, 1964.

20. Moura RAA. Técnicas de laboratório. 2nd. ed. Atheneu, São Paulo, 1982.

21. Organización Mundial de la Salud. Normalización de las técnicas de estudio de la glucosa-6-fosfato deshidrogenasa. Série de Informes Técnicos 366: 1-257, 1967.

22. Padilha-Gonçalves A. Estudo das concentrações sanguíneas das sulfonamidas no decurso do tratamento da blastomicose brasileira. O Hospital 29: 875-881, 1946.

23. Paniker NV, Beutler $E$. The effect of methylene blue and diaminodiphenylsulfone on red cell reduced glutathione synthesis. Journal of Laboratory Clinical Medicine 80: 481-487, 1972.

24. Peters JH, Gordon GR, Brown P. The relationship between the capacities of human subjects to acetylate isoniazid, sulfanilamide and sulfamethazine. Life Sciences 4: 99-107, 1965.

25. Snedecor GW, Cochran WG. Statistical methods. Ames Iowa State University, 1980.

26. Sunahara S, Urano M, Ogawa M. Genetica and geographical studies in isoniazid inactivation. Science 134: 1530-1531, 1961.

27. Vree TB, O'Reilly WJ, Kekster YA, Damsma JE, Van der Kleijin E. Determination of the acetylator phenotype and pharmacokinetics of some sulphonamides in man. Clinical Pharmacokinetics 5: 274-294, 1980. 